А. Біла-Кисельова,

кандидат юридичних наук, юрист-міжнародник, суддя

Білозерського районного суду Херсонської області

\title{
ПРОБЛЕМНІ ПИТАННЯ ЩОДО ГАРМОНІЗАЦІЇ НАЦІОНАЛЬНОГО ЗАКОНОДАВСТВА 3 МІЖНАРОДНИМИ СТАНДАРТАМИ
}

Постановка проблеми. Для удосконалення законодавства України щодо питання протидії корупції та розвитку державної служби в Україні (вільної від проступків державних службовців, злочинів у сфері державної служби) потрібно додаткове вивчення міжнародного досвіду та стандартів, вироблених міжнародними організаціями, які застосовуються в іноземних країнах. Це підтверджується представленням НАЗК проекту для публічного обговорення під назвою «Антикорупційна стратегія на 2020-2024 роки» [1].

До принципів стратегії належить оптимізація функцій держави; забезпечення дієвого державного контролю за дотриманням публічними службовцями правил етичної поведінки та вимог антикорупційного законодавства; забезпечення невідворотності юридичної відповідальності за корупційні та пов'язані 3 корупцією правопорушення.

Щодо визначення правових та організаційних засад запобігання, виявлення та припинення корупції в публічній сфері, відшкодування заподіяної корупційними правопорушеннями шкоди, поновлення прав та законних інтересів осіб, держави, регулювання міжнародного співробітництва у сфері протидії корупції можна говорити лише тоді, коли буде проведена гармонізація українського законодавства 3 міжнародними зобов'язаннями та правовими стандартами, які розробили та рекомендують застосовувати міжнародні організації (використовують іноземні країни). Проблемних питань, які потребують вивчення та вирішення, багато, тому заявлена тема є актуальною.

Аналіз останніх досліджень і публікацій. Питанню дослідження юридичної відповідальності державних службовців приділяли увагу А.В. Акуліч, О.І. Дубовик, О.Д. Лазор, А.П. Рачинський та інші вчені.

Зазначене питання в опції міжнародних документів, які мають складати основу стандартів для національного законодавства в розрізі «поведінка державного службовця юридична відповідальність - попередження корупції», не досить вивчено.

Метою статті $€$ аналіз визначення сутності «юридичної відповідальності державних службовців» на національному та міжнародному рівнях; аналіз законодавства іноземних країн, яке регулює питання державної служби, а також дослідження міжнародних документів, що регламентують поведінку державних службовців і мають використовуватися для протидії корупції.

Виклад основного матеріалу. Корупція загрожує демократії, правам людини, соціальній справедливості, перешкоджає економічному розвитку України та ставить під загрозу стабільність демократичних інститутів та етичних норм суспільства. 
У Резолюції (97) 24 Комітету Міністрів Ради Європи «Про 20 принципів боротьби з корупцією» зазначено: «Гарантувати, що правила, які стосуються прав і обов'язків посадових осіб, містять вимоги до боротьби з корупцією і забезпечують відповідні та ефективні дисциплінарні заходи; мають просувати подальшу специфікацію поведінки, очікуваної від громадських посадових осіб, такими як кодекси поведінки» [2].

Регіональний документ закликає національні владні структури застосовувати принципи у внутрішньому законодавстві та на практиці, а також закликає Мультидисциплінарну групу 3 корупції (далі - GMC) закінчити розробку міжнародних юридичних інструментів відповідно до програми дій проти корупції.

Відповідно до статті 2 Конвенції $\mathrm{OOH}$ «Проти корупції (універсального документу) «державна посада означає будь-яку особу, яка обіймає посаду в законодавчому, виконавчому, адміністративному або судовому органі держави-учасниці, яку призначено чи обрано, праця якої оплачувана чи не оплачувана незалежно від старшинства [3].

У Рекомендації № R(2000)10 Комітету Міністрів державам-членам Ради Європи щодо кодексів поведінки державних службовців зазначається, що «державний службовець є особою, яка працюе в публічному органі» (регіональний документ) [4]. Завданням зазначеного документу $€$ визначення стандартів честі та поведінки, яких повинні дотримуватися державні службовці, надання їм допомоги у дотриманні цих стандартів та інформування громадськості про те, на яку поведінку державних службовців вона може сподіватися.

Відповідно до статті 8 Конвенції $\mathrm{OOH}$ «Проти корупції» «з метою боротьби з корупцією кожна держава-учасниця заохочує inter alia непідкупність, чесність і відповідальність своїх державних посадових осіб згідно з основоположними принципами своєї правової системи. Зокрема, кожна держава-учасниця прагне застосовувати в рамках своїх інституціональних і правових систем кодекси або стандарти поведінки для правильного, добросовісного й належного виконання державних функцій» [3].

$\mathrm{y}$ науці є офіційна позиція, згідно якої відповідальність державних службовців настає за порушення норм закону, службової дисципліни, невиконання (неналежне виконання) посадових обов'язків. На практиці питання притягнення до дисциплінарної відповідальності державних службовців і притягнення за корупційні діяння залишається проблемним через недосконалості законодавства та прогалини, які нині існують. Про це свідчать рішення судів з Єдиного державного реєстру судових рішень. Теоретично можна говорити, що відповідальність державних службовців пов'язана $з$ наслідками їх поведінки, тобто 3 неналежним виконанням (невиконанням) службових обов'язків.

А.П. Рачинський зазначає, що «юридична відповідальність держслужбовця гармонійно пов'язується із вихідними ідеями службової діяльності, а також необхідністю неухильного дотримання державної та службової дисципліни, вимог законності та панування права у державі. Юридична відповідальність державного службовця - це правові наслідки примусового характеру, які об'єктивуються в результаті протиправної поведінки держслужбовця у зв'язку 3 виконанням чи неналежним виконанням покладених на нього службових обов'язків [5, с. 14].

Службова дисципліна включає такі складники: неухильне дотримання Присяги державного службовця; сумлінне виконання службових обов'язків; дотримання правил внутрішнього службового розпорядку (ст. 2 Закону України «Про державну службу»). 3 огляду на зазначене законодавцем при розгляді можливого 
порушення державним службовцем слід враховувати, чи був приведений до присяги державний службовець; чи достеменно відомо особі їі обов'язки та стандарти поведінки для певної категорії осіб; чи повідомлений державний службовець про поняття «близька особа», «корупційне правопорушення», «реальний конфлікт інтересів», «пряме підпорядкування».

3 огляду на те, яку позицію зайняти, можна виділити два протилежних ставлення державних службовців до реалізації своїх обов'язків: держслужбовець вибудовує свою діяльність відповідно до вимог, які йому пред'явлені «посадовими стандартами поведінки», 3 огляду на позитивне ставлення до них; службовець не виконує (частково не виконує), умисно унеможливлює виконання свого обов'язку в достатній мірі, виходячи із негативного ставлення до «посадових стандартів поведінки» [6, с. 465].

О.Д. Лазор і О.Я. Лазор О. вважають, що необхідною умовою настання юридичної відповідальності $€$ наявність трьох підстав:

1) фактичної (склад правопорушення);

2) нормативної (норми права);

3) процесуальної (акт застосування права).

Фактичною підставою застосування юридичної відповідальності здебільшого $є$ вчинення правопорушення, під яким розуміють суспільно небезпечне або шкідливе діяння, що порушує норму права. Правопорушення включає об'єкт (суспільні відносини, на які посягає правопорушник); об'єктивну сторону (противоправну сторону, настання наслідків і наявність зв'язку між діянням та наслідками); суб'єкт (деліктоздатну особу, яка вчинила правопорушення); суб'єктивну сторону (вину правопорушника).

Нормативною підставою $є$ невиконання чи неналежне виконання встановленого державою обов'язку, закріпленого у диспозиції відповідної юридичної норми, яку порушують, закономірним наслідком чого є застосування до особи встановлених санкцій. Процесуальна підстава виражається в акті застосування правової норми [7, с. 252-253].

Як встановлено, юридична відповідальність державних службовців $€$ засобом впливу на поведінку, яка $€$ неправомірною. А.В. Акуліч зазначає: «Відповідальність є формою захисту прав, свобод та законних інтересів фізичних і юридичних осіб у державі від неправомірних дій і перевищення службових повноважень» [8, с. 14].

Для кращого розуміння про порядок регулювання питання державної служби в іноземних країнах наведемо приклади законодавства іноземних держав щодо питання державної служби та етики державних службовців. Так, законодавство Республіки Таджикистан у питанні щодо державної служби за своїм змістом майже збігається 3 національним. Закон Республіки Таджикистан «Про державну службу» містить окрему норму щодо визначення етики державних службовців, яка має відсильний характер, вказуючи на нормативно-правовий акт, який регулює це поняття [9]. Указом Президента Республіки Таджикистан введено в дію Кодекс етики державного службовця, який наголошує на визначенні особливої відповідальності державного службовця перед суспільством і базується на принципах законності, дотримання прав людини, чесності; містить норми щодо відповідальності за корупційні правопорушення [10].

Основними засадами, на яких базується державна служба Республіки Казахстан, є такі принципи: принцип законності, казахстанського патріотизму, єдності системи державної служби, професіоналізму, ефективності, результативності, прозорості, етичності, підконтрольності та підзвітності, нетерпимості до правопорушень (Закон «О государственной службе Республики Казахстан» від 23.11.2015) [11].

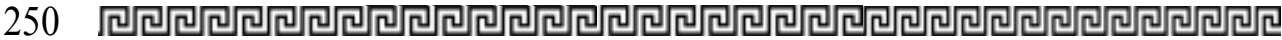


Республіка Молдова прийняла Закон «Про непідкупність» від 25 травня 2017 року та Закон «Про конфлікт інтересів», що регулює несумісності та обмеження, встановлені стосовно осіб, які займають відповідальні державні або інші передбачені цим законом посади, а також порядок подання декларацій про конфлікт інтересів [12, 13].

Республіка Білорусь у Законі «Про державну службу в Республіці Білорусь» зазначила, що «державний службовець несе відповідальність за невиконання або неналежне виконання з вини державного службовця покладених на нього службових обов'язків, перевищення посадових повноважень, порушення трудової та виконавської дисципліни, а також за недотримання встановлених цим Законом та іншими законодавчими актами обмежень, пов'язаних із державною службою» [14].

Слід звернути увагу й на те, що у Німеччині наслідки невиконання (неналежного виконання) державними службовцями покладених на них обов'язків регламентовані у Статуті федерального дисциплінарного права. Державний службовець вважається винним у здійсненні службового проступку, якщо він порушив порядок виконання покладених на нього обов'язків.

Якщо діï, вчинені державним службовцем, були поза службою i суттєво зачіпають інтереси його служби (відомства), то вони розглядаються як проступок. Кожен вчинок (проступок) впливає на рівень поваги та довіри людини і суспільства до відомства, органу (посади, яку займає службовець). Однак не кожне порушення обов'язків тягне за собою застосування мір відповідальності [15, c. 144].

У Республіці Польща встановлено, що якщо $з$ вини державного службовця сталася втрата його повноважень (втрачені навики, які потрібні для здійснення службових повно- важень), то розірвання трудового контракту та звільнення відбувається без повідомлення. Законодавством Франції, на відміну від українського законодавства, передбачена за вчинення корупційних дій виключно кримінальна відповідальність [15, с. 123].

Висновок. Можна зробити висновок, що юридична відповідальність державних службовців $є$ засобом, що мав би попередити неправомірну поведінку осіб, які присвятили себе публічній службі. Прогалини у законодавстві України щодо державної служби все-таки існують.

Про стандарти поведінки державні службовці мають поверхневе уявлення, але не завжди їх дотримуються. Це пов'язано з тим, що роками в органи державної влади в часи Радянського Союзу влаштовуватися цілі сім'ї, які продовжують працювати й нині (привели своїх нащадків і родичів в організації, якими керують). Наприклад, чоловік і дружина працювали в одному державному органі, але на різних посадах. Це стосувалося й батьків, хрещених і хрещеників. Таке заміщення посад родичами в державних органах не допустимо, 3 цим явищем потрібно боротися. Слід залучати фахівців для виявлення «родинних кланів» в органах державної служби та доводити до відома про таке явище відповідні правоохоронні органи, припиняючи таку «родинну діяльність».

Крім того, досі не відбулося повної гармонізації національного законодавства 3 міжнародними стандартами у сфері протидіï корупції, державної служби. Для реалізації заходів подолання та попередження корупції в умовах сьогодення можна використовувати такі шляхи: розроблення методичних рекомендацій для державних службовців 3 питань розв'язання конфліктів інтересів і дотримання етичних норм у своїй діяльності 3 урахуванням стандартів, які запропоновано регіональними документами; притягнення винних 
осіб до відповідальності за вчинення корупційних діянь та інших правопорушень, пов'язаних із корупцією; щоквартальне висвітлення інформації на сайтах органів державної влади щодо скоординованої та попереджувальної політики з приводу подолання корупції (виконання заздалегідь розроблених і впроваджених дорожніх карт); проведення відкритих конкурсів з метою зайняття посад в органах державної служби з представниками суспільства (громадськими радами, 3MI); залучення міжнародних фахівців і національних фахівців зі знаннями міжнародного права до конкурсних (спостережувальних) рад, які опікуються процесом добору осіб на публічну службу в Україні (просування по кар'єрі).

У статті висвітлено проблемні питання, пов'язані з гармонізацією національного законодавства з міжнародними стандартами в рамках запропонованої НАЗК "Aнтикорупиійної cmpamezіï на 2020-2024 роки».

Проаналізовано законодавство іноземних країн (Республіки Таджикистан, Республіки Казахстан, Республіки Білорусь, Pеспубліки Молдова, Республіки Польща, Німеччини) щодо питання проходження державної служби (конфлікт інтересів, етика державних службовиів). Представлено наукову думку щодо визначення поняття «юридична відповідальність державного службовия в результаmi протиправної поведінки». Вивчено міжнародні документи, якими регламентовано введення понять «державна посада», «державний службовецьь», «принциипи боротьби з корупиією».

Для дотримання міннародних зобов'язань за універсальними та регіональними договорами, попередження корупції запропоновано такі шляхи вирішення проблеми: розроблення методичних рекомен- даиій для державних службовиів з питань розв'язання конфліктів інтересів $i$ дотримання етичних норм у своїи діяльності з урахуванням стандартів, запропонованих регіональними документами; притягнення винних осіб до відповідальності за вчинення корупційних діянь та інших правопорушень, пов'язаних із корупциєю; щзквартальне висвітлення інформації на сайтах органів державної влади щзодо скоординованої ma попереджувальної політики з приводу подолання корупції (виконання заздалегідь розроблених $i$ впроваджених дорожніх карт); проведення відкритих конкурсів з метою зайняття посад в органах державної служби з представниками суспільства (громадськими радами, ЗМI); залучення міжнародних фахівиів $і$ національних фахівців зі знаннями міжнародного права до конкурсних (спостережувальних) рад, які опікуються процесом добору осіб на публінну службу в Україні.

Ключові слова: міжнародні стандарти, корупція, державна служба, антикорупційна стратегія.

Bila-Kyseleva A. Problem issues regarding the harmonization of national legislation to international standards

The article highlights the problematic issues related to the harmonization of national legislation with international standards in the framework of the proposed NAPC "AntiCorruption Strategy for 2020-2024".

The legislation of foreign countries (Republic of Tajikistan, Republic of Belarus, Republic of Moldova, Republic of Poland, Germany) on the issue of civil service (conflict of interest, ethics of civil servants) is analyzed. The scientific opinion on the definition of "legal liability of a civil servant and the result of illegal behavior" is presented. International 
documents regulating the introduction of the concepts "public office", "civil servant", "principles of combating corruption" were studied.

To comply with international obligations under universal and regional treaties, to prevent corruption, the following ways are proposed: development of guidelines for civil servants on resolving conflicts of interest and adherence to ethical norms in their activities, taking into account the standards proposed by regional documents; bringing the perpetrators to justice for corruption and other corruption-related offenses; quarterly coverage of information on the websites of public authorities on coordinated and preventive policies to combat corruption (implementation of pre-developed and implemented roadmaps); conducting open competitions for positions in the civil service with representatives of society (public councils, the media); involvement of international specialists and national specialists with knowledge of international law in competition (supervisory) councils, which take care of the process of selection of persons for public service in Ukraine.

Key words: international standards, corruption, civil service, anti-corruption strategy.

\section{Література}

1. Cайm НАЗК (Антикорупційна стратегія на 2020-2024 роки, проект для публічного обговорення). URL: https: / / nazk.gov.ua/uk/departamentkoordynatsiyi-antykoruptsijnoyi-polityky/ antykoruptsijna-strategiya/.

2. Резолюиія (97) 24 Комітету Міністрів Ради Європи «Про 20 принициів боротьби з корупцією». URL: http:// nkkspk.com.ua/UK/rezolyuciya-97-24komiteta-ministrov-soveta-evropy-odvadcati-principax-borby-s-korrupciej/.

3. Конвенція ООН «Проти корупції. URL: https://zakon.rada.gov.ua/laws / show/995_c16\#Text.
4. Рекомендація № $R(2000) 10$ Комітету Міністрів державам-иленам Ради Європи щодо Кодексів поведінки державних службовиів. URL: http: / / wre. dridu.dp.ua/cpk/Lib/7_Zapobigannya\% 20 ta\% 20 protydiya\% 20 proyavam\% 20korup / Legislation / Legislature/Rekomend_poved_ DS.pdf.

5. Рачинський А.П. Статус державного службовия в Україні: теоретико-правовий аспект : автореф. дис. канд. наук з держ. управ.: 25.00.03. Київ, 2000. $22 \mathrm{C}$.

6. Потьомкіна Ю.С. Категорія «відповідальність» у сфері державної служби. Університетські наукові записки. Хмельницький. 2012. № 3(43). С. 460-468.

7. Лазор О.Д., Лазор О.Я. Державна служба в Україні: навч. посібник. 3-тє вид., допов. і перероб. Київ : Дакор, 2009. $560 \mathrm{c}$.

8. Акуліч А.В. Особливості правового статусу працівника прокуратури як суб'єкта трудового права : автореф. дис. канд. юрид. наук: 12.00.05. Луганськ, 2010. 22 c.

9. «О государственной службе»: Закон Pеспублики Такжикистан от 05.03.2007 № 233. URL: http://base.spinform.ru/ show_doc.fwx?rgn $=16591$.

10. Кодекс этики государственного служащего : Указ Президента Pеспублики Таджикистан от 15.09.2010 № 932. URL: http://base.spinform.ru/show_doc. fwx? rgn $=32697$.

11. «O государственной службе Pеспублики Казахстан» от 23.11.2015. URL: http: / / mdai.gov.kz.

12. «O конфликте интересов»: Закон Республики Молдова от 15.02.2008 № 16-XVI. URL: http://lex.justice.md/ $\mathrm{ru} / 327989 /$.

13. «O неподкупности»: Закон Pеспублики Молдова от 25.05.2017 № 82. Офиииальный монитор Республики Молдова. 2017. № 229-243. Cm. 360 .

14. «O государственной службе в Республике Беларусь»: Закон Республики Беларусь от 14.06.2003 № 204-3 (в ред. от 09.01.2017). URL: http:// www.pravo.by/ document $/$ ?guid $=3871 \& p 0=h 10300204$.

15. Государственная служба зарубежных стран : сб. обз. законод. / под. ред. Касаткина Н.м. Москва: РАН, 1996. 166 c. 